Товарознавчий вісник. - 2018. - Випуск 11.

УДК 676.255.332

С.В. ПУТІНЦЕВА, Г.А. ТІХОСОВА, Н.А. ФЕДЯКІНА

Херсонський національний технічний університет

\title{
ТОВАРОЗНАВЧА ОЦНКА ЯКОСТІ ПАПЕРУ НА ОСНОВІ ЦЕЛЮЛОЗИ 3 ВОЛОКОН ЛЬОНУ ОЛІЙНОГО
}

\author{
С.В. ПУТИНЦЕВА, А.А. ТИХОСОВА, Н.А. ФЕДЯКИНА \\ Херсонский национальный технический университет
}

\section{ТОВАРОВЕДЧЕСКАЯ ОЦЕНКА КАЧЕСТВА БУМАГИ НА ОСНОВЕ ЦЕЛЛЮЛОЗЫ ИЗ ВОЛОКОН ЛЬНА МАСЛИЧНОГО}

\author{
S. PUTINTSEVA, H. TIKHOSOVA, N. FEDYAKINA \\ Kherson National Technical University
}

\section{COMMODITY EVALUATION OF QUALITY OF PAPER MADE FROM PULP FROM FLAX OIL}

\author{
https://doi.org/10.36910/6775-2310-5283-2018-11-15
}

Мета. Здійснити комплексну оиінку якості фільтрувального паперу із композицій деревної целюлози та целюлози з волокон льону олійного.

Методика. При дослідженнях використовували передбачені діючими державними стандартами методи, які дозволяють вивчити споживні властивості фільтрувального паперу на основі иелюлози з волокон льону олійного.

Результати. Проведено комплексну оцінку якості нового фільтрувального паперу, фільтрувального паперу ТОВ «Цюрупинська паперова компанія» та встановлено, щчо комплексний показник запропонованого паперу на 3\% більший за відповідне значення фільтрувального паперу за ТУУ 21.1-32104275-001:2009. Це дає можливість стверджувати про доцільність впровадження запропонованого фільтрувального паперу у виробництво та використання у паперовій промисловості.

Наукова новизна. Встановлені закономірності впливу целюлози з волокон льону олійного на функиіональні та естетичні властивості та надійність споживання одержаного фільтрувального паперу.

Практична значимість. Розроблено композицію для одержання фільтрувального паперу на основі целюлози з волокон льону олійного з покращеними функціональними властивостями, яка забезпечує надійність споживання отриманого паперу за рахунок оптимального вмісту рослинної целюлози, яка є безпечною для людини під час виробництва та використання.

Ключові слова: товарознавче оцінювання, фільтрувальний папір, целюлоза з волокон льону олійного, комплексний показник якості, функиіональні властивості, надійність споживання.

Постановка проблеми у загальному вигляді та іï зв'язок із важливими науковими чи практичними завданнями. Для товарознавчого 
оцінювання якості зразків фільтрувального паперу на основі целюлози 3 волокон льону олійного із різним відсотковим вмістом деревної целюлози та целюлози 3 волокон льону олійного доцільно використовувати комплексний показник якості. Він дозволяє характеризувати загальний рівень якості досліджуваних об’єктів із різним складом та відсотковим співвідношенням компонентів i визначати відповідність споживних властивостей фільтрувального паперу на основі целюлози 3 волокон льону олійного вимогам нормативно-технічної документації та потребам споживачів $[1,2]$. Це забезпечить вибір оптимального поєднання та вмісту складових композиції для одержання паперу залежно від його функціонального призначення.

Аналіз останніх досліджень, у яких започатковано вирішення проблеми. Промислову паперову продукцію поділяють на групи за функціональним призначенням. Залежно від цього якість одержаного паперу повинна відповідати визначеним показникам якості, що обумовлені державними стандартами [3].

В роботі було визначено основні показники якості, за якими можна встановити функціональне призначення отриманого паперу.

Отже, папір, одержаний на основі целюлози $з$ волокон льону олійного (новий папір), за номенклатурою показників якості найбільше відповідає фільтрувальному паперу, тому його можна віднести до групи фільтрувальних паперів. Для розрахунку комплексного показника його якості як базові можна прийняти показники якості фільтрувального паперу згідно з ГОСТ 12026-76 «Бумага фильтровальная лабораторная. Технические условия» [4] та ГОСТ 20358-78 «Бумага для фильтрования воздуха. Технические условия» [5].

Цілі статті полягають у визначенні відносних показників якості фільтрувального паперу на основі целюлози з волокон льону олійного та проведенні його товарознавчого оцінювання за допомогою комплексного показника якості.

Об’єкти досліджень. Об‘єктом дослідження є фільтрувальний папір, одержаний на основі целюлози з волокон льону олійного.

Виклад основного матеріалу дослідження 3 повним обгрунтуванням отриманих наукових результатів. Визначення відносних показників якості

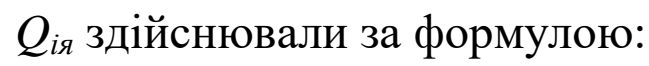

$$
Q_{\text {iq }}=\frac{P_{i}}{P_{\text {баз }}},
$$

де $\quad P_{i}-$ значення $i$-го показника $(i=1,2,3 \ldots n)$ якості продукції, що оцінюється; 
$P_{\text {баз }}-$ базове значення $i$-го показника.

Результати визначення відносних показників якості фільтрувального паперу наведено в табл. 1.

Таблиця 1

Відносні показники якості досліджуваного фільтрувального паперу

\begin{tabular}{|c|c|c|c|c|}
\hline \multirow{2}{*}{$\begin{array}{l}\text { № } \\
\text { 3/П }\end{array}$} & \multirow{2}{*}{ Назва показника якості } & \multicolumn{2}{|c|}{ Значення показника якості } & \multirow{2}{*}{$\begin{array}{c}\text { Значення } \\
\text { відносного } \\
\text { показника } \\
\text { якості, } Q_{i я}\end{array}$} \\
\hline & & $\begin{array}{c}\text { нового } \\
\text { фільтрувального } \\
\text { паперу } \\
\end{array}$ & за стандартом & \\
\hline 1. & Maca $1 \mathrm{M}^{2}, \Gamma$ & 97,0 & 75,0 & 1,3 \\
\hline 2. & Фільтрувальна здатність, с & 28,1 & 45,0 & 1,6 \\
\hline 3. & $\begin{array}{l}\text { Повітропроникність, л / } \\
\left(\mathrm{M}^{2} \cdot \mathrm{c}\right)\end{array}$ & 750 & 830 & 0,9 \\
\hline 4. & Білість, \% & 80 & 83 & 1,0 \\
\hline 5. & Засміченість, шт. & 95 & 100 & 1,1 \\
\hline 6. & Опір на розривання, $\mathrm{H}$ & 25,6 & 21,0 & 1,2 \\
\hline 7. & Опір на зламування, к.п.п. & 20 & 30 & 0,7 \\
\hline
\end{tabular}

На рис. 1 представлено шкалу відношень для вимірювання рівня якості фільтрувального паперу. Ламана лінія - це рівень якості паперу, одержаного із композиції деревної целюлози та целюлози з волокон льону олійного, а пряма лінія - рівень якості фільтрувального паперу згідно з чинними стандартами.

Проведено комплексне оцінювання якості досліджуваних зразків фільтрувального паперу, що відповідає вимогам чинних стандартів, виготовленого ТОВ «Цюрупинська паперова компанія» та одержаного із запропонованої композиції на основі целюлози з волокон льону олійного, за показниками функціональних, естетичних властивостей i надійності споживання методами кваліметрії з побудовою структури показників якості, яка представлена на рис. 2 [6].

Аналіз табл. 1 і рис. 1 та 2 свідчить, що частина відносних показників якості нового паперу більша чи дорівнює одиниці, а частина менша за одиницю, тому необхідно було визначити комплексний показник якості досліджуваного паперу. 
Товарознавчий вісник. - 2018. - Випуск 11.

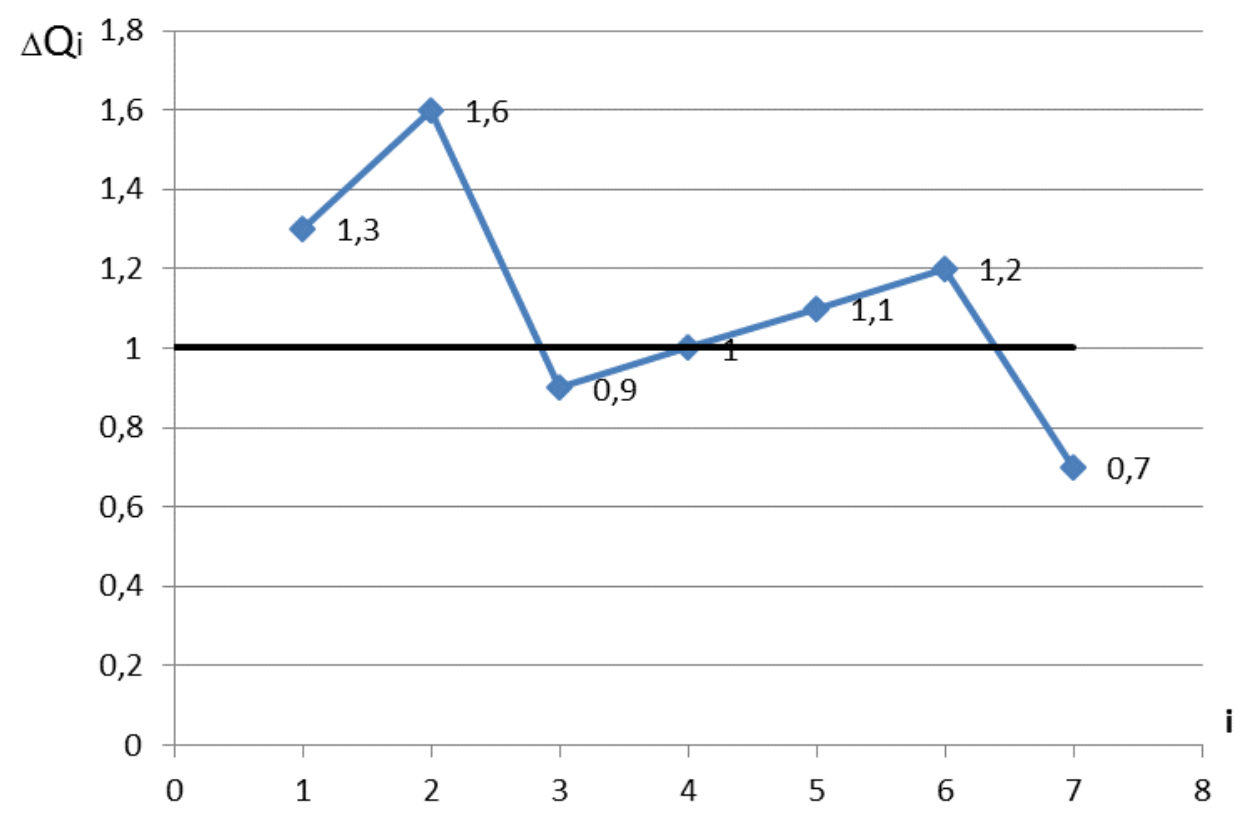

Рис. 1. Шкала відношень для вимірювання рівня якості нового паперу

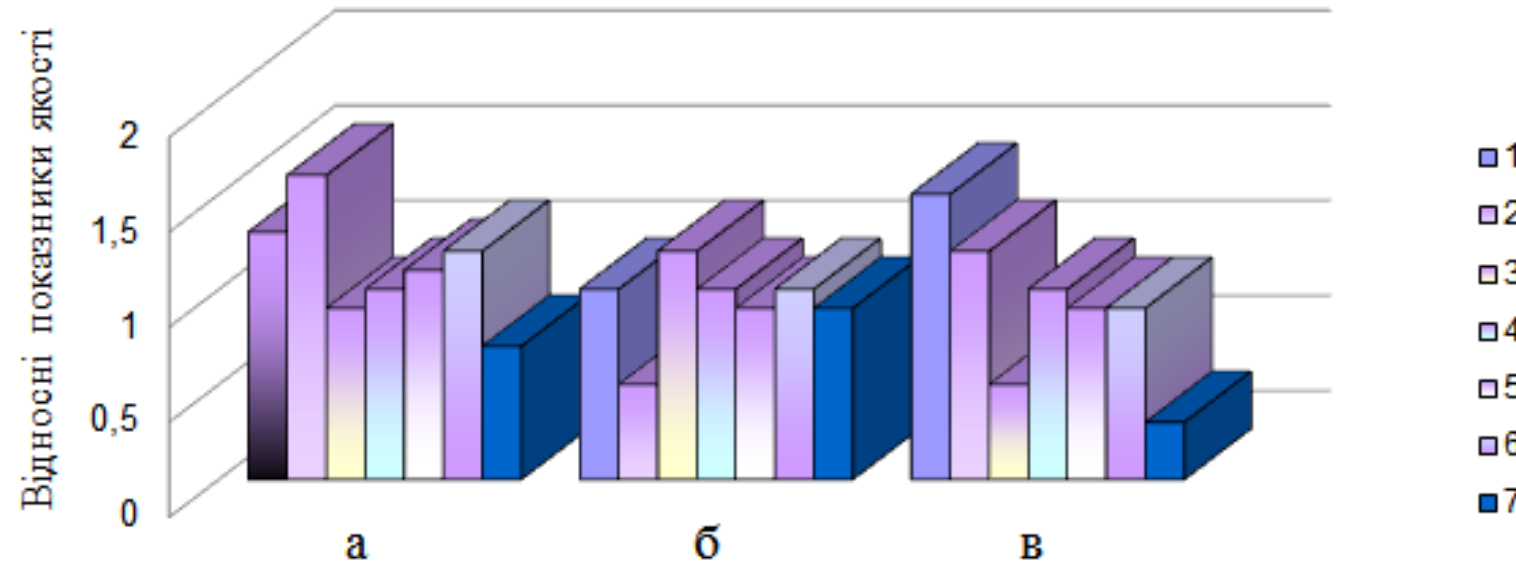

Варіанти зразків

Рис. 2. Структура показників якості: а - нового фільтрувального паперу, б - за стандартом, в - фільтрувального паперу виробництва ТОВ «Цюрупинська паперова компанія»:

1 - маса 1 м²; 2 - фільтрувальна здатність; 3 - повітропроникність; 4 - білість; 5 засміченість; 6 - опір на розривання; 7 - опір на зламування

Для цього шляхом ранжування показників якості експертним методом розраховували вагомість кожного показника. Отримані результати наведено в табл. 2. 
Товарознавчий вісник. - 2018. - Випуск 11.

Коефіцієнти вагомості кожного показника визначали за формулою:

$$
q_{i}=\Sigma m_{i} / \Sigma \Sigma m_{i},
$$

де $\quad m_{i}$ - оцінка вагомості $i$-го показника кожним експертом.

Таблиия 2

Ранжування показників якості фільтрувального паперу

\begin{tabular}{|c|l|c|c|c|c|c|c|c|}
\hline \multirow{2}{*}{$\begin{array}{c}\text { № } \\
\text { 3/п }\end{array}$} & \multirow{2}{*}{ Назва показника якості } & \multicolumn{5}{|c|}{ Оцінки експертів } & \multirow{2}{*}{ Сума $m_{i}$} & \multirow{2}{*}{$q_{i}$} \\
\cline { 2 - 8 } & & 1 & 2 & 3 & 4 & 5 & & \\
\hline 1. & Маса 1 м² & 5 & 5 & 5 & 4 & 5 & 24 & 0,171 \\
\hline 2. & Фільтрувальна здатність & 6 & 7 & 7 & 7 & 6 & 33 & 0,236 \\
\hline 3. & Повітропроникність & 2 & 1 & 1 & 1 & 2 & 7 & 0,050 \\
\hline 4. & Білість & 4 & 3 & 2 & 3 & 1 & 13 & 0,093 \\
\hline 5. & Засміченість & 1 & 2 & 3 & 2 & 3 & 11 & 0,078 \\
\hline 6. & Опір на розривання & 7 & 6 & 6 & 6 & 7 & 32 & 0,229 \\
\hline 7. & Опір на зламування & 3 & 4 & 4 & 5 & 4 & 20 & 0,143 \\
\hline \multicolumn{2}{|c|}{ Разом } & 28 & 28 & 28 & 28 & 28 & 140 & 1,000 \\
\hline
\end{tabular}

Результати розрахунків, здійснених за експертним методом, свідчать, що найбільш вагомими 3 перелічених показників $\epsilon$ ті, які мають найбільші значення коефіцієнтів вагомості $q_{2}=0,236$ і $q_{6}=0,229$, тобто фільтрувальна здатність та опір на розривання.

Використавши результати проміжних розрахунків в роботі було визначено, що коефіцієнт конкордації становить: $K_{u}=0,897$, що свідчить про наявність високого ступеня узгодженості думок експертів і дозволяє оцінити узгодження рішень експертів на задовільно.

Для визначення комплексного показника якості розраховували середній опосередкований арифметичний показник якості за формулою:

$$
\bar{Q}_{c b a}=\sum_{i=1}^{n} q_{i} Q_{i \imath},
$$

де $Q_{i я}-$ відносний показник якості;

$q_{i}$ - коефіцієнт вагомості кожного показника якості.

Дані для розрахунку комплексного показника якості наведені в табл. 3.

У результаті розрахунку комплексного показника якості нового фільтрувального паперу, одержаного на основі композиції деревної целюлози та целюлози 3 волокон льону олійного, встановлено, що середній опосередкований арифметичний показник якості дорівнює 1,20. 


\section{Розрахунок комплексного показника якості} нового фільтрувального паперу

\begin{tabular}{|c|c|c|c|c|}
\hline \multirow{2}{*}{ Назва показника якості } & \multicolumn{2}{|c|}{ Значення показника якості } & \multirow{2}{*}{$\begin{array}{c}\text { Значення } \\
\text { відносного } \\
\text { показника } \\
\text { якості, } Q_{\text {iя }}\end{array}$} & \multirow{2}{*}{$\begin{array}{c}\text { Коефіцієнт } \\
\text { вагомості за } \\
\text { експертними } \\
\text { оцінками, } q_{i}\end{array}$} \\
\hline & $\begin{array}{l}\text { нового } \\
\text { паперу }\end{array}$ & за стандартом & & \\
\hline Maca $1 \mathrm{M}^{2}, \Gamma$ & 97,0 & 75,0 & 1,3 & 0,171 \\
\hline Фільтрувальна здатність, с & 28,1 & 45,0 & 1,6 & 0,236 \\
\hline $\begin{array}{l}\text { Повітропроникність, } \\
\text { л / }\left(\mathrm{M}^{2} \cdot \mathrm{c}\right)\end{array}$ & 750 & 830 & 0,9 & 0,050 \\
\hline Білість, \% & 80 & 83 & 1,0 & 0,093 \\
\hline Засміченість, шт. & 95 & 100 & 1,1 & 0,078 \\
\hline Опір на розривання, $\mathrm{H}$ & 25,6 & 21,0 & 1,2 & 0,229 \\
\hline Опір на зламування, к.п.п. & 20 & 30 & 0,7 & 0,143 \\
\hline
\end{tabular}

$\bar{Q}_{c b a}=1,3 \cdot 0,171+1,6 \cdot 0,236+0,9 \cdot 0,050+1,0 \cdot 0,093+1,1 \cdot 0,078+1,2 \cdot 0,229+0,7 \cdot 0,143=1,2$

За даними ТОВ «Цюрупинська паперова компанія», яка $є$ провідним виробником фільтрувального паперу в Україні, комплексний показник якості фільтрувального паперу на основі деревної та бавовняної целюлози, виготовленого за ТУ У 21.1-32104275-001:2009 «Бумага фильтровальная технического назначения» [7], становить 1,02.

Комплексні показники якості фільтрувального паперу за ГОСТ 12026-76 «Бумага фильтровальная лабораторная. Технические условия» [4] i ГОСТ 20358-78 «Бумага для фильтрования воздуха. Технические условия», фільтрувального паперу, виготовленого ТОВ «Цюрупинська паперова компанія» [5], та нового фільтрувального паперу на основі целюлози 3 волокон льону олійного наведено в табл. 4 і на рис. 3.

Оскільки комплексний показник якості нового фільтрувального паперу на основі целюлози з волокон льону олійного становить 1,20 , а інших зразків (фільтрувального паперу за чинними стандартами, фільтрувального паперу TOB «Цюрупинська паперова компанія») - 1,06 і 1,02 відповідно, то можна стверджувати, що новий фільтрувальний папір має кращі споживні властивості.

Таблиця 4 
Товарознавчий вісник. - 2018. - Випуск 11.

Комплексний показник якості досліджуваних зразків паперу

\begin{tabular}{|l|c|}
\hline \multicolumn{1}{|c|}{ Фільтрувальний папір } & Значення комплексного показника якості \\
\hline $\begin{array}{l}\text { Фільтрувальний папір за чинними } \\
\text { стандартами }\end{array}$ & 1,06 \\
\hline $\begin{array}{l}\text { Фільтрувальний папір ТОВ } \\
\text { «Цюрупинська паперова компанія» }\end{array}$ & 1,02 \\
\hline $\begin{array}{l}\text { Новий фільтрувальний папір на } \\
\text { основі целюлози з волокон льону } \\
\text { олійного }\end{array}$ & 1,20 \\
\hline
\end{tabular}

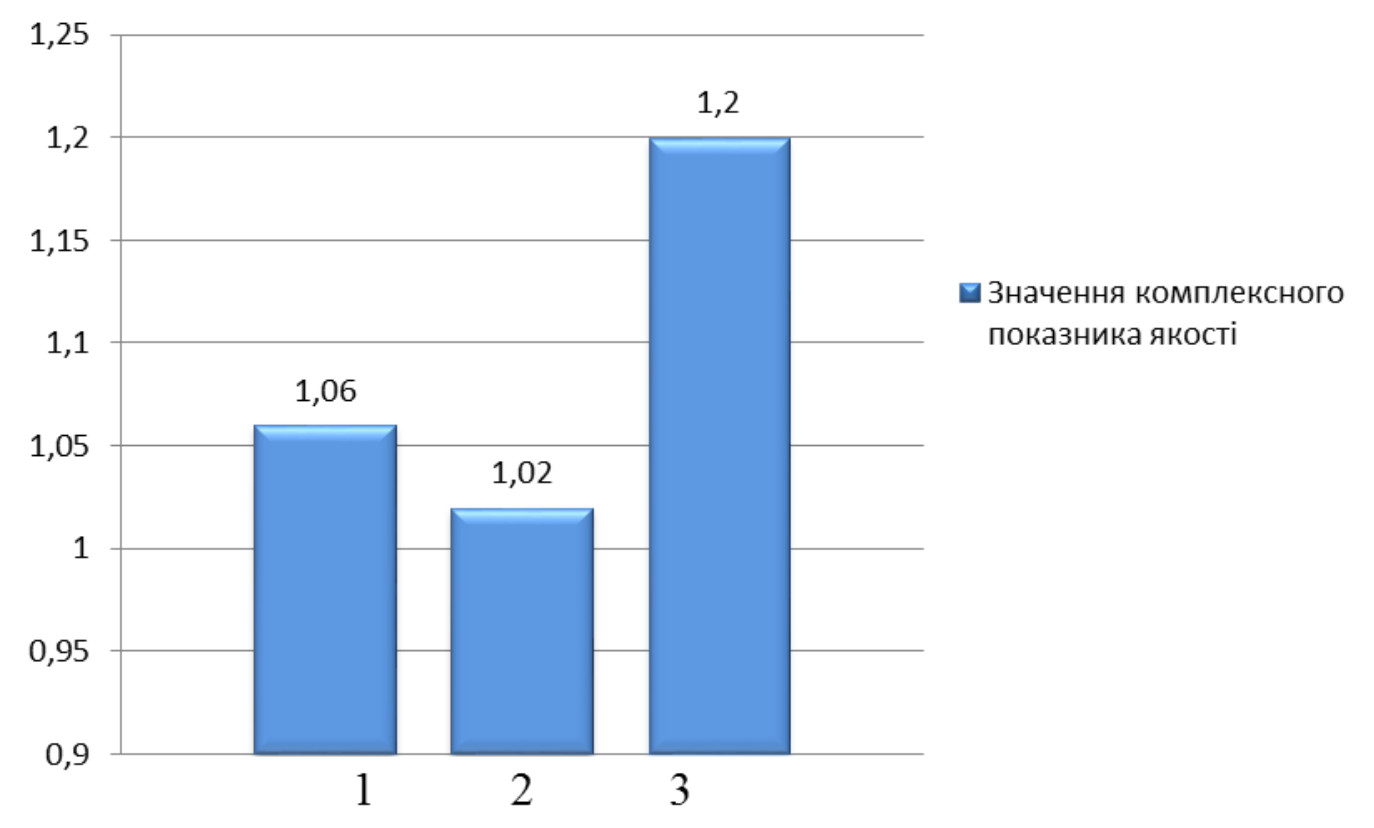

Рис. 3. Комплексний показник якості фільтрувального паперу:

1 - за чинними стандартами; 2 - ТОВ «Цюрупинська паперова компанія»; 3 - на основі целюлози з волокон льону олійного

Висновки та перспективи подальших досліджень. Таким чином, високий комплексний показник якості, як і окремі показники функціональних, естетичних властивостей та надійності споживання, $є$ підтвердженням доцільності виробництва нового лабораторного фільтрувального паперу на основі целюлози з волокон льону олійного.

Крім визначення комплексного показника якості, необхідно також здійснити комплексне інтегральне оцінювання конкурентоспроможності нового фільтрувального паперу, одержаного на основі композиції деревної целюлози та целюлози з волокон льону олійного. 


\section{Література}

1.Чурсіна Л.А. Товарознавча характеристика паперу, одержаного із целюлози льону олійного / Чурсіна Л.А., Горач О.О., Граділь Л.В. // Товарознавчий вісник. - 2011. - Вип. 3. - C. 322-326.

2. Пугачевський Г.Ф. Товарознавство непродовольчих товарів: підручник для студ. вищ. закл. освіти / Г.Ф. Пугачевський, Б.Д. Семак. - К.: Укоопосвіта, 1999. - 596 с.

3. Боженко Л.І. Управління якістю, основи стандартизації та сертифікації продукції: навчальний посібник / Л.І. Боженко, О.Й. Гутта. - Львів, 2001. - 176 с.

4. Бумага фильтровальная лабораторная. Технические условия: ГОСТ 12026-76. [Введен в действие с 01.01.1978]. - М.: Стандартинформ, 2007. - 6 с. (Межгосударственный стандарт).

5. Бумага для фильтрования воздуха. Технические условия: ГОСТ 20358-78. [Введен в действие с 01.01.1980]. - М.: ИПК Издательство стандартов, 2010. - 6 с. (Межгосударственный стандарт).

6. Фомин В.Н. Квалиметрия. Управление качеством. Сертификация: учеб. пособие / В. Н. Фомин. - М.: Ось-89, 2002. - 384 с.

7. Бумага фильтровальная технического назначения: ТУ У 21.1-32104275001:2009. - [Введены в действие с 01.01.2010]. - Херсон: Херсонстандартметрология, 2010. - 17 с. - (Технические условия Украины).

Цель. Осуществить комплексную оценку качества фильтровальной бумаги из композиций древесной целлюлозы и целлюлозы из волокон льна масличного.

Методика. При исследованиях использовали предусмотренные действуюшими государственными стандартами методы, которые позволяют изучить потребительские свойства фильтровальной бумаги на основе целлюлозы из волокон льна масличного.

Результаты. Проведена комплексная оценка качества новой фильтровальной бумаги, фильтровальной бумаги ООО «Цюрупинска бумажная компания» и установлено, что комплексный показатель предложенной бумаги на 3 \% выше соответствующего значения фильтровальной бумаги по ТУ 21.1-32104275-001: 2009. Это дает возможность утверждать о целесообразности внедрения предложенной фильтровальной бумаги в производство и использование в бумажной промышленности.

Научная новизна. Установлены закономерности влияния цееллюлозы из волокон льна масличного на функииональные и эстетические свойства и надежность потребления полученной фильтровальной бумаги.

Практическая значимость. Разработана композищия для получения фильтровальной бумаги на основе целлюлозы из волокон льна масличного с улучшенными функциональными свойствами, которая обеспечивает надежность потребления полученной бумаги за счет оптимального содержания растительной целлюлозы, которая является безопасной для человека при производстве и использовании.

Ключевые слова: commodity evaluation, фильтровальная бумага, целлюлоза из волокон льна масличного, комплексный показатель качества, функциональные свойства, надежность потребления. 
Purpose. To carry out a comprehensive assessment of the quality of filter paper from wood pulp and cellulose compositions from flax fiber.

Methodology. During the studies, the methods provided by the current state standards were used, which allow us to study the consumer properties of filter paper based on cellulose from flax oil.

Findings. A comprehensive assessment of the quality of the new filter paper, filter paper LLC "Tsyurupinsk paper company» and found that the complex index of the proposed paper is 3 $\%$ higher than the corresponding value of the filter paper according to TU 21.1-32104275-001: 2009. This makes it possible to assert the feasibility of implementing the proposed filter paper into production and use in the paper industry.

Originality. The regularities of the influence of cellulose from the flax oil on the functional and aesthetic properties and reliability of consumption of the obtained filter paper are established.

The practical value. A composition for producing filter paper based on cellulose pulp from flax fibers with improved functional properties has been developed which ensures the reliability of consumption of the obtained paper due to the optimal content of plant cellulose that is safe for man during production and use.

Keywords: commodity assessment, filter paper, cellulose from flax fiber, an integrated indicator of quality, functional properties, reliability of consumption.

Стаття рекомендована до друку доктором технічних наук, професором ХНТУ Кузьміною Т.О. Стаття надійшла в редакиію 03.08.2018 р. 